\title{
Characteristics of an Effective Child Protection System in the European and International Contexts
}

\author{
Mariëlle R. Bruning ${ }^{1}$ (D) Jaap E. Doek ${ }^{1}$
}

Accepted: 24 June 2021/Published online: 31 August 2021

(C) The Author(s) 2021

\begin{abstract}
In the European context, an understanding that States are responsible for an effective child protection system is well established. Further, all 47 members of the CoE have adopted the European Convention for the Protection of Human Rights and Fundamental Freedoms, and all European countries have ratified the UN Convention on the Rights of the Child (CRC). Thus, States have come to understand their responsibility in terms of the child's right to protection. The aim of this article is to explicate core elements of an effective child protection system within a child's rights framework. This aim is accomplished by highlighting and providing analysis of the principles set forth in the CRC and further elaborated in General Comment No. 13 (2011) and by the UN Children's Fund (UNICEF), the main components of policies and other relevant documents of the European Union (EU) and the Council of Europe $(\mathrm{CoE})$, and caselaw from the European Court of Human Rights (ECrtHR) and then presenting recommendations for an effective State-run child protection system.
\end{abstract}

Keywords Child protection $\cdot$ Children's rights $\cdot$ Child protection systems $\cdot$ Positive obligations states $\cdot$ Multi-agency cooperation

\section{Introduction}

The protection of children has a long history. For many centuries, it was to a large degree a matter of charity on the part of religious and other civil society organizations. In Europe, the structure started to change at the end of the nineteenth century. Legislative and other measures in inter alia the UK, France, Belgium, and the Netherlands established a law-based child protection system recognizing the obligation of the

Mariëlle R. Bruning

m.r.bruning@law.leidenuniv.nl

1 Leiden Law Faculty, Child Law Department, Leiden University, PO Box 9520, 2300 RALeiden, Netherlands 
State (government) to ensure that children would receive protection when needed. Over time, child protection responsibilities were shared with civil society organizations funded by the State, and child protection became professionalized and increasingly specialized. Indeed the development of specialized organizations in the field of physical and mental health care and social work resulted in a patchwork of agencies and services with no or little sharing of information. This situation has meant that parents had to share their problems and challenges multiple times to individuals within a variety of organizations, all of which provide little support to address the root causes of the problems they are experiencing in caring for their children. Some very tragic incidents, some resulting in the preventable death of a child, made the public and the relevant (State and non-State) agencies aware of the urgency to improve the operational efficiency and effectiveness of the child protection system. For instance, in the UK and the Netherlands, inquiry committees were established to investigate and analyze serious fatal or almost fatal incidents, diagnose the problems, and present recommendations for legislative, administrative, and other measures (Bruning \& Zlotnik, 2019; Dutch Safety Board, 2011; Langeland et al., 2015; Munro Review, 2011; van Nijnatten et al., 2014).

It should be noted that since the beginning of the last century, explicit attention for abuse and neglect of children was rather limited. The exception was the UK, in which the National Society for the Prevention of Cruelty against Children (NSPCC) in 1889. This organization was given (by law) the statutory power to apply for care and supervision orders of children at risk ${ }^{1}$ and established local services centers across the UK. In 2006, the organization established a child line to give young people a voice when no one is listening. ${ }^{2}$

This lack of attention changed rather significantly during the second part of the twentieth century due to actions undertaken by C. Henry Kempe, a pediatrician in Denver, Colorado, and his colleagues (Krugman \& Korbin, 2013). His advocacy efforts led to the introduction in all states of the USA of reporting laws requiring, at a minimum, certain professionals working with or for children to report incidences or suspicions of child maltreatment. Similar laws were introduced in Australia and Canada in the 1960s and 1970s. A movement, the International Society for the Prevention of Child Abuse and Neglect (ISPCAN), was established to promote prevention of child abuse and neglect and effective intervention when necessary (Donnelly, 2002).

A hugely significant development for child protection was the adoption of the Convention on the Rights of the Child (CRC) by the UN General Assembly on 20 November 1989. The CRC, which has been ratified by 196 countries, requires countries to recognize their responsibility for the implementation of the right of children to protection. In effect, it is the government's responsibility to ensure an effective child protection system. This idea raises a critical question: What are the key elements that make a child protection system effective?

The aim of this article is to explicate core elements of an effective child protection system within a child's rights framework. This aim is accomplished by highlighting and

\footnotetext{
${ }^{1}$ This law: Prevention of Cruelty to, and Protection of Children Act 1889, also known as the Children's Charter. An important piece of legislation, 100 years before the Convention on the Rights of the Child was adopted by the UN General Assembly.

${ }^{2}$ For more information, see: http://www.nspcc.org.uk/keeping-children-safe/our-services/childline.
} 
providing analysis of the principles set forth in the CRC and further elaborated in General Comment No. 13 (2011) and by the UN Children's Fund (UNICEF), the main components of policies and other relevant documents of the European Union (EU) and the Council of Europe (CoE), and caselaw from the European Court of Human Rights (ECrtHR) and then presenting recommendations for an effective State-run child protection system.

\section{Key Elements of an Integrated and Effective Child Protection System: International and European Developments}

\section{International Developments}

\section{CRC and General Comment No. 13}

At the global level, the Convention on the Rights of the Child (CRC) provides a number of its articles' principles for a comprehensive and effective child protection system. The obligations of States parties to protect children from all forms of exploitation, abuse, and neglect can be found in the articles 19 and 32-38 CRC and in the optional protocols to the CRC. ${ }^{3}$ Article 19 is considered as laying the foundation for protection of children against all forms of abuse and violence, as defined in para. 1 of that provision. This is confirmed by the CRC Committee, which is charged with monitoring the implementation of the CRC, in its General Comment No. 13 (2011; Doek et al., 2020). ${ }^{4}$ Before discussing article 19 and General Comment No. 13 (2011), some attention must be given to articles 2, 3, par. 1, 6, and 12 which the CRC Committee considers as the general principles of the CRC. The provisions in these articles have to be taken into account in the implementation of all other articles of the CRC, including article 19.

Article 2 underscores that States parties shall take adequate measures to ensure to every child the right to protection from all forms of violence without any discrimination of any kind as specified in this article. It includes discrimination based on prejudices towards commercially sexually exploited children and other children in potentially vulnerable situations (General Comment CRC No. 13, para. 60, 72 g). Article 3, para. 1 requiring that in all actions concerning children the best interests of the child shall be the primary consideration must be interpreted in a manner consistent with the whole Convention (General Comment No. 14 (2013) served inter alia by adequate investment in human, financial, and technical resources dedicated to the implementation of a child

\footnotetext{
${ }^{3}$ The Optional protocols to the Convention on the Rights of the Child on the sale of children, child prostitution, and child pornography (OPSC) and on the involvement of children in armed conflict (OPAC). Both optional protocols were adopted by the UN General Assembly Resolution of 25 May 2000 (A/RES/54/ 263 ) and entered into force respectively on 18 January 2002 and 12 February 2002 and currently ratified by 175 States (OPSC) and 167 States (OPAC).

${ }^{4}$ General Comments are documents issued by the CRC Committee (as well as by other human rights treaty bodies) in which it provides State parties to the CRC with guidance on the implementation of a specific article or on the implementation of the CRC for specific groups of children such as children with disabilities, indigenous children, and children living on the street. So far the CRC Committee has issued 24 General Comments. The full text of these General Comments can be found at: http://www2.ohchr.org/english/bodies/ crc/comments.htm.
} 
rights-based and integrated child protection and support system (General Comment CRC No. 13, para. 61). ${ }^{5}$ Article 6 on the right to life, survival, and development is obviously relevant for the protection of children from all forms of violence. Article 12 provides the child with the right to freely express her/his views and the right that these will be given due weight in accordance with the age and maturity. The Committee is of the view that it is a mandatory step at every point in a child protection process that the views of the child are invited and given due weight. The experience of violence is disempowering, and sensitive measures are needed to ensure that the child protection interventions do not further disempower children but rather contribute positively to their recovery and reintegration via carefully facilitated participation. It is furthermore important that children participate in the development of prevention strategies, e.g., in schools, in particular in the elimination and prevention of bullying and other forms of violence in schools (General Comment CRC No. 12, para. 63).

In its General Comment No. 13, the CRC Committee specifies the many different forms of violence against children that are covered by article 19, para. 1, and provides a legal analysis of para. 2, elaborating on actions required by this provision, such as identification, reporting (should be mandatory for professionals working with or for children), referral, investigation, judicial involvement, and treatment. The Committee underscores the necessity of a child rights approach to child protection which requires a paradigm shift away from child protection approaches in which children are perceived and treated as objects in need of assistance rather than as rights holders entitled to nonnegotiable rights to protection.

In the context of efforts to develop an integrated and effective child protection system, the CRC Committee's recommendations regarding the establishment of a national coordinating framework on violence against children are important (General Comment CRC No. 13, para. 68-71). This framework can be a mechanism for communication between government and civil society actors against violence against children. It can promote flexibility and creativity, allowing for the development and implementation of new initiatives. How such a framework is established is left to the States parties, as their existing legal, institutional, and service infrastructures differ. Further, cultural customs and professional competencies are quite different (Gilbert et al., 2011; Merkel-Holguin et al., 2019).

However, the Committee is of the view that there are elements which have to be mainstreamed into this national framework: a child rights approach (see above); the gender dimensions of violence against children addressing inter alia gender discrimination and gender-based stereotypes; primary (general) prevention; the primary position of families in child caregiving and protection strategies; and resilience and protective factors such as stable families, nurturing child-rearing by adults, nonviolent discipline, and secure attachment with at least one adult. Furthermore, proactive, tailored measures have to be taken to reduce risk factors, and special attention should be given to children in potentially vulnerable situations; human, financial, and technical resources must be allocated to the maximum extent of available resources (General Comment CRC No. 13, para. 72(a)-(j)).

\footnotetext{
${ }^{5}$ General Comment No 13, para. 61. See for more information about the meaning and implementation of article 3, para. 1 also General Comment No.14 (2013) on the right of the child to have his or her best interests taken as a primary consideration (art.3, para. 1). UN Doc. CRC/C/GC/14, 29 May 2013.
} 


\section{UNICEF's Approach}

Since 2008, UNICEF adopted an approach to child protection which seeks to ensure that children are being protected in a holistic manner fully consistent with their rights. Important components of a child protection system are human resources, finances, laws and policies, governance, monitoring and data collection, protection and response services, and care management. It also includes different actors: children, families, communities, those working at subnational or national level, and those working internationally (UNICEF, 2019, 5). UNICEF emphasizes the importance of relationships and interaction between and among these components and actors.

In order to have a fully functional child protection system, UNICEF is of the view that six crucial elements need to be in place (UNICEF, 2019):

1. A robust legal and regulatory framework, as well as specific policies related to child protection

2. Effective governance structures, including coordination across government departments, between levels of decentralization and between formal and informal actors

3. A continuum of services (spanning prevention and response)

4. Minimum standards and oversight (information, monitoring, and accountability mechanisms)

5. Human, financial, and infrastructure resources.

6. Social participation, including respect for children's own views and an aware and supportive public

\section{Implementation}

The recommendations of the CRC Committee in GC No. 13 are meant for all 196 States parties to the CRC. In addition, the Committee provides States parties, after the examination of their reports, with country-specific recommendations in its concluding observations (COs). ${ }^{6}$ For instance, the Committee has urged the State party Australia to provide the Assistant Minister for Children and Families with a clear mandate and sufficient authority to coordinate all activities related to the implementation of the Convention at the cross-sectoral, federal, state, territory, and local levels. ${ }^{7}$ For Botswana, the Committee has recommended that it strengthens its coordination efforts, including by ensuring that the National Children's Council has sufficient authority to coordinate all activities related to the implementation of the Convention. ${ }^{8}$ Countryspecific recommendations are also made on the obligations of States parties enshrined in article 19 such as legislative measures to prohibit corporal punishment. ${ }^{9}$ Other

\footnotetext{
${ }^{6}$ Concluding observations (COs) is the name of a document the Committee issues after it has examined the report of a State party and which contains appreciations for the progress made and concerns at the remaining shortcomings in the implementation of the CRC followed by specific recommendations to address them.

${ }^{7}$ Concluding observations on the combined fifth and sixth periodic reports of Australia, UN Doc. $\mathrm{CRC} / \mathrm{C} /$ AUS/CO/5-6, 1 November 2019, para. 9.

${ }^{8}$ Concluding observations on the combined second and third reports of Botswana, UN Doc. CRC/C/BWA/ CO/2-3, 26 June 2019, para. 10.

${ }^{9}$ Concluding observations on the combined fifth and sixth reports of Belarus, UN Doc. CRC/C/BLR/CO/5-6, 28 February 2020, para. 7.
} 
specific recommendations include strengthening efforts to combat cyberbullying and harassment against lesbian, gay, bisexual, transgender, and intersex children; ensuring child-friendly, accessible complaint mechanisms in schools or through electronic platforms; and safeguarding the privacy of the child victims, ${ }^{10}$ to speed up the establishment of child-friendly reporting, complaint, and referral mechanisms for child victims of abuse ${ }^{11}$ and to encourage community-based programs aimed at preventing domestic violence child abuse and neglect. ${ }^{12}$

Although the recommendations are non-binding, States parties are expected to give appropriate follow-up. They are the result of a rather extensive and well-documented examination of the performance of a State party in its implementation of the CRC and issued by a body of 18 experts elected by the States parties. Experiences over the last 30 years show that most actions are legislative measures, e.g., by amending existing laws or introducing new ones in order to prohibit all forms of violence including corporal punishment in all settings such as institutions, schools, and the family. Issues like bullying in school are dealt with in many countries via awareness raising campaigns in which the serious and long-lasting negative consequences of this form of violence are presented, the explicit prohibition of bullying in schools, and the development of protocols and training programs for teachers. Experiences also show that civil society, in particular NGOs and professional associations (social work, psychologists, etc.), use the recommendations as a tool in their actions (public pressure and lobbying) to improve the child protection practice in their countries.

An example of an international $\mathrm{NGO}$ active at the national and international level is the Global Initiative to End All Corporal Punishment of Children. This NGO has since 2001 undertake a variety of action for the prohibition of all forms of corporal punishment. It succeeded in moving the number of countries that has a full prohibition of corporal punishment from 11 in 2001 to 60 in 2020, while it is prohibited in all schools in 132 countries. However, 732 million school-age children between 6 and 17 years live in countries where corporal punishment at school is not fully prohibited. ${ }^{13}$

Children are increasingly, and in compliance with article 12 CRC, involved in these actions. Appropriate follow-up means that States parties can and should take into account factors such as their legal system and available resources while deciding what their priorities are. The CRC Committee does not impose priorities, although it will, where necessary, express a certain urgency.

The evaluation of UNICEF's strategies and programs (UNICEF, 2019) ${ }^{1415}$ found inter alia that achievements in legislative and policy reform have not yet translated into strengthened governance and coordination structure. The health sector in particular was

\footnotetext{
${ }^{10}$ Concluding observations on the combined fifth and sixth periodic reports of Costa Rica. UN Doc. CRC/C/ CRI/CO/5-6, 4 March 2020, para. 24 (c) and 25; concluding observations on the fifth and sixth periodic reports of Italy, UN Doc. CRC/C/ITA/CO/5-6, 28 February 2019, para. 20; Concluding Observations on the fourth and fifth periodic reports of Japan; UN Doc. CRC/C/JPN/CO/4-5, 5 March 2019, para. 25 (a) and (b).

${ }^{11}$ Concluding observations Costa Rica, para. 27 (d).

12 Concluding observations Japan, para. 24 (a).

${ }^{13}$ Concluding observations Italy, para. 19 (d).

${ }^{14}$ Global Initiative to End All Corporal Punishment of Children, Briefing paper July 2020. Unfortunately, this NGO had to close its actions per 1 September 2020 due to the lack of adequate funding, despite the many efforts undertaken to secure this funding.

${ }^{15}$ This evaluation was conducted in 24 different countries from all regions of the world (Latin America 3, Europe 4, Africa and MENA region 11, and Asia-Pacific 6).
} 
rarely found to be well integrated into child protection systems work. Furthermore, in some countries, there is no clear lead ministry on child protection; in others, multiple ministries have related or overlapping mandates. A major bottleneck in most countries is the inability of formal systems to reach down to community level to provide effective prevention and response services where child rights violations actually occur. According to UNICEF, investments in capacity building sharply increase the potential for functional child protection systems (UNICEF, 2019, 18).

\section{Some Conclusions}

The developments at the international level since the beginning of this century show that there is a rather clear consensus among the leading agencies (CRC Committee and UNICEF) of what is necessary to establish an integrated and effective child protection system. The CRC Committee provides States parties to the CRC with specific recommendations meant to improve the quality and effectiveness of the child protection system, e.g., re the coordination of activities of different agencies, the provision of the necessary human and financial resources, and the importance of data collection. Furthermore, the CRC Committee makes country-specific recommendations on the prevention of and interventions in cases of child abuse and neglect and other forms of violence against children (Art. 19 CRC). Since 2015, the Committee also has reminded States parties of their commitment to eliminate by 2030 of all forms of violence and (commercial and sexual) exploitation of children as specified in the targets 5.2., 5.3, 8.7, and 16.2 of the Sustainable Development Goals (SDGs). ${ }^{1617}$ It goes beyond the scope of this article to elaborate more on these targets relevant for the protection of children. However, it is a major challenge for the 196 States parties to the CRC for the next 10 years to achieve these targets. The best action to that effect is in our view to give priority to investment of human and financial resources to the maximum extent possible (Art. $4 \mathrm{CRC}$ ) in the full implementation of the CRC.

\section{European Developments}

In Europe, two bodies play an important role in the promotion of integrated child protection systems at the national level: the European Commission (with 28 Member States), more specifically the European Union Agency for Fundamental Rights (FRA), and the Council of Europe (CoE) (with 47 Member States), with its Children's Rights Division.

\footnotetext{
${ }^{16}$ General Comment No 8: The right of the child to protection from corporal punishment and other cruel or degrading forms of punishment (articles 19; 28, para. 2; and 37, inter alia) was adopted at the 42nd session of the CRC Committee (15 May-2 June 2006), UN Doc CRC/C/GC/8. 2 March 2007 (re-issued for technical reasons). This GC can be considered as a contribution to UN Study on violence against children. The report of the independent expert for the United Nations study on violence against children (UN Doc. A/61/209) was presented at the UN General Assembly in October 2006.

${ }^{17}$ The SDGs were adopted by the United Nations General Assembly, A/RES/70/1. Transforming our world: the 2030 Agenda for Sustainable Development, 25 September 2015. Target 5.2.and 5.3. on elimination of violence against girls and of harmful practices; target 8.7. on ending child labor in all its forms; target 16.2. to end abuse, exploitation, trafficking, and all forms of violence against and torture of children. See for indicators to measure the results of the efforts to achieve these targets: A Generation to Protect. Monitoring violence, exploitation, and abuse of children within the SDG framework. New York: UNICEF 2020.
} 


\section{European Union Agency for Fundamental Rights (FRA): Key Components and Principles of Child Protection}

The FRA observed that child protection has historically focused on particular issues or specific groups of children. But this fragmented "systems of" child protection fails to provide a comprehensive solution for the diverse needs of children and is neither sustainable nor effective. Therefore, the European Union (EU) emphasizes the importance of developing EU guidance on integrated child protection systems. It calls on Member States to strengthen child protection systems, underlining that comprehensive child-sensitive protection systems that ensure interagency and multi-disciplinary coordination are key in catering to diverse needs of diverse groups of children (EU Trafficking, 2012-2016). This integrated child protection system places the child at its center, endorses and promotes the $\mathrm{CRC}$, and ensures that all essential actors and systems (e.g., education, health, welfare, justice, civil society, community, family) work in concert to prevent child abuse, exploitation, neglect, and other forms of violence against children and to protect and assist children in these situations. The FRA considers the following areas as the main components of child protection systems:

- National and legislative and regulatory framework, including child protection policies

- National authorities responsible for child protection and service providers

- Human and financial resources focusing on qualification and training of personnel

- Identification and reporting procedures for children in need of protection and procedures for placing children in alternative care

- Accountability and monitoring systems focusing on the monitoring and development of common quality indicators

\section{Implementation}

In 2015, the EU conducted a mapping of the performance on each of these components by the 28 Member States (EU mapping child protection, 2015). A brief summary of the key findings of this mapping exercise:

a. Eighteen Member States have a key legal instrument devoted to child protection, which addresses identification, referral, and assessment of child victims of violence, abuse, and neglect. However, the fragmentation of and limitation to national legal frameworks keep certain vulnerable groups of children, such as children with disabilities, children belonging to ethnic minorities, and unaccompanied and separated children from receiving adequate and quality services.

b. Thirteen Member States have a specific national policy or strategy on child protection, but these strategies are not always accompanied by concrete action plans with specific time-bound and measurable goals.

c. The majority of Member States do not have a single authority with overall child protection responsibilities. These responsibilities are often shared among different ministries and across national, regional and local authorities. Thirteen Member States established a distinct authority to coordinate and often monitor the implementation of national policy and legislation. 
d. In all Member States, vetting procedures exist for persons that are foster parent candidates. But only seven of them have a specific timeline for the frequency of the reviews, varying form once every 5 years to every year. Eight Member States have specific provisions for the frequency of reviews and checks following the initial vetting of residential care personnel. The procedures require, as a minimum, checking of criminal records for acts of sexual abuse and exploitation of children. In some countries, the procedures also require mental health and psychological reports.

e. The legal obligation to report cases of child abuse, neglect, and violence exists in 15 Member States for all professionals working with or for children. In 10 Member States, this obligation is limited to certain professional groups such as social workers and teachers. In many States, the anonymity of reporting professionals is not always guaranteed which may discourage them from reporting. Fifteen Member States have specific reporting obligations for civilians in addition to the general obligation for all citizens to report a criminal act.

f. The right of the child to be heard is enshrined in the law of all Member States. In 11 Member States, an age is set at which the respective authorities have the obligation to provide the child with an opportunity to express their views and listen to them. For children below that age, it depends on the respective authority and her or his assessment of the maturity and evolving capacities of the child whether the child will be given this opportunity. This discretionary power exists for all children in countries that have not set an age at which the child must be heard.

\section{Council of Europe (CoE) Policy Guidelines}

In 2009, the Committee of Ministers of the CoE adopted the guidelines on integrated national strategies for the protection of children from violence. The Member States of the CoE should promote the implementation of the guidelines, ensure the widest possible dissemination, and cooperate with the $\mathrm{CoE}$ in developing, implementing, and monitoring the national strategies.

One of the aims of the Guidelines is to promote the adoption, implementation, and monitoring of integrated national strategies for the protection of children from violence. The general principles of the guidelines are the same as the ones identified by the CRC Committee: non-discrimination (Art. $2 \mathrm{CRC}$ ); the best interests of the child as a primary consideration in all actions regarding children (Art. 3 (1) CRC); the right to life, survival, and development (Art. $6 \mathrm{CRC}$ ); and the right to express views and be heard (Art. 12).

The main components of a national strategy on child protection are:

- A legal framework that is in compliance with the $\mathrm{CRC}^{18}$ and covers among others prevention, prohibition of violence, the role of corporate actors, sanctions and measures, jurisdiction, and enforcement.

- A policy framework that includes as a crucial element a national child policy for the realization of the child's right to be protected from all forms of violence.

\footnotetext{
${ }^{18}$ See the CoE's Strategy for the Rights of the Child (2016-2021).
} 
Furthermore, children and families' policies should be part of this framework with the goal to support families in their child rearing responsibilities, prevent as much as possible the separation of the child from her/his family, and provide community based family like alternative care.

- An institutional framework with the following key elements: a national agency with the primary responsibility for protection of children from violence and with coordinating and monitoring function concerning the implementation of the national strategy, a clearly defined role of each of the public institution contributing to child protection, the establishment of an independent human rights institution, the accreditation and registration of all institution providing care and services for children, and the adoption of codes of good conduct by all these institutions.

\section{Implementation}

In 2018, the CoE conducted a survey among Member States in the framework of intergovernmental activities carried out within the Ad hoc Committee on the Rights of the Child (CAHENF). The survey aimed to take stock of responses of Member States to different forms of violence against children through the development and implementation of integrated national strategies for the protection of children from violence, as defined in the guidelines on integrated national strategies. Thirty-eight Member States participated in the survey by providing national responses in a detailed questionnaire that was prepared by the Expert Group Violence Against Children of the CAHENF.

The CoE, 2019 report "A Life Free from Violence" on actions taken by the CoE and Member States shows that important progress has been made since the adoption of the policy guidelines. A majority of the Member States have significant measures in place, both at the legislative and at policy level, to protect children from violence. ${ }^{19}$ Eightyfour percent of the Member States have either a national integrated strategy or other specific, integrated policy measures in place: 26 out of the 38 responding Member States indicated that they have developed an integrated strategy on violence against children, whereas 6 Member States indicated that they had adopted some other integrated approaches through specific policy instruments. Such strategies often contain clear targets, an established time frame, and resources for its implementation. In the survey, 29 out of the 38 responding Member States confirmed to have a legislative framework in place that allows for the whole range of legal interventions needed for prevention, protection, prohibition of violence against children, and sanctions for those who commit an offense (CoE, 2019, para. 117). The greatest progress has been made in the domestic setting and the school environment. A multi-stakeholder approach has been developed, and an intersectoral cooperation to provide children with adequate protection is clearly visible in many Member States. Furthermore, the responses showed that children living in institutions have not benefitted from the same attention as children in home and school settings (CoE, 2019, para. 201).

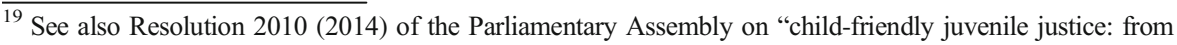
rhetoric to reality".
} 


\section{Some Conclusions}

It is clear from the information presented that key intergovernmental actors in the implementation of children's rights in Europe (EU and $\mathrm{CoE}$ ) are since about 10 years advocating for the development and implementation of an integrated child protection system. These two actors agree more or less on the key or crucial components or elements of an integrated child protection system. They are:

- A national legislative and regulatory framework

- An institutional framework that includes inter alia the establishment of a national agency with the primary responsibility for child protection ensuring the coordination of all activities of the governmental and non-governmental actors in child protection, accreditation, registration, and regular vetting of all institutions and professionals providing care and services to children and the provision of adequate human and financial resources

- Accountability and monitoring systems, including the establishment of an independent human rights institution such as a children's ombudsperson ${ }^{20}$ and the development of common quality indicators

It should be noted that the $\mathrm{CoE}$ is not very specific on the promotion of an integrated child protection system. The Guidelines (2010), including the legal framework, focus on the protection of children from violence. ${ }^{21}$ In the presentation of the main components of child protection systems, the EU does not explicitly refer to violence against children, but its mapping exercise shows that the focus is very much on children as victims of violence.

The 2015 mapping of the EU and the 2018 survey of the CoE show that European countries undertake a variety of actions and they indicate that progress has been made and that these countries are on the road to the establishment of a national integrated child protection system. But still, a lot more needs to be done.

For instance, the European focus on violence against children does not pay attention to the fact that not all protection needs of children are related to violence that they suffer or witness. Children may, e.g., show external problematic behavior or may affiliate themselves with deviant peers that may be difficult for parents to handle and could require protective measures. In addition, children must be protected from discrimination, e.g., because of their disability, from economic exploitation and from recruitment and involvement in armed groups or forces. A comprehensive (and integrated) child protection system should be covering more than incidences of violence. However, a vast majority of children in need of protection are victims of violence in all its different forms.

The main part of the presentation of the ideas on an integrated child protection system deals with organizational issues. However, there is a need for more guidance on

\footnotetext{
${ }^{20}$ See for more information about this element of a child protection system General Comment No. 2 (2002) on the role of independent national human rights institutions in the promotion and protection of the rights of the child (UN Doc. CRC/GC/2002/2, 15 November 2002).

${ }^{21}$ The same focus can be found in the CoE Strategy for the Rights of the Child in which a life free of violence for all children is a priority area, Chapter III of the Strategy CM Documents, CM92015) 175-final, 3 March 2016.
} 
what could or should be done in terms of concrete legislative, social, or administrative measures to implement and enforce the rights of the child.

In the next part of this article, we shall pay specific attention to some of the rights of the child that should play a role in an integrated child protection system using the caselaw of the European Court on Human Rights. Caselaw related to both articles 3 (protection against torture and inhuman and degrading treatment) and 8 (inter alia on the right to respect for private and family life) of the European Convention on Human Rights is decisive in defining children's rights related to child protection (against violence) and includes positive obligations for Member States. Different from child protection systems principles in policy papers or standards, the provisions of the ECHR and the judgments of the ECtHR are directly applicable, and this leads to the enforceability of core principles of child protection systems. The next paragraph shall cover substantive issues such as the right of the child not to be separated from your parents unless it is necessary in her/his best interests (Art. 9 para. 1 CRC) and procedural issues such as the right of the child to be heard (Art. 12 CRC).

\section{Fundamental Rights of the Child in an Integrated Child Protection System: Caselaw of the European Court on Human Rights}

\section{Protection of Children from Violence}

In line with the special attention given by the European Union and the CoE in their promotion of integrated child protection systems to violence against children, several principles can be distilled from relevant caselaw of the European Court on Human Rights (ECtHR). In this paragraph, we shall first present caselaw of the ECtHR dealing with violence against children. It will become clear that based on relevant caselaw, both substantive and procedural obligations can be distinguished to prevent ill-treatment and to investigate ill-treatment against children (article 3 ECHR; O'Mahony, 2019b). At the same time, the family's right to respect for family and private life has to be guaranteed in light of positive obligations in that regard (article 8 ECHR); this will be discussed in the second part.

\section{Protection Against Violence in the Family}

The child's right to protection against all forms of violence as an important impetus for child protection systems is not explicitly mentioned in the ECHR. Article 3 ECHR does not specify in any way "violence against children", but emphasizes the right to be protected against inhuman or degrading treatment. Still, according to the ECtHR's interpretation, child abuse or neglect can satisfy the standard of cruel, degrading, or inhuman treatment under Article 3 ECHR. The "living instrument" doctrine that was established in the Tyrer $v$ United Kingdom case $e^{22}$ has influenced the interpretation of the ECHR ever since (O'Mahony, 2019b). According to this standard, a "minimum level of severity" must be attained, depending on the nature and content of the punishment and the method of its execution. This follows from the landmark decision in the Tyrer

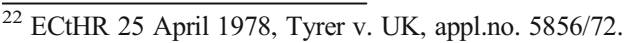


case, in which a 15-year-old boy was given three strokes of the birch in 1972 administered over the bare posterior, according to the local juvenile court's sentence. Tyrer was hit by policemen in private in the presence of Tyrer's father and a doctor.

The ECtHR has stressed that the State can be held responsible for breaches of the ECHR that occur in the private sphere, such as the beating of a boy by his stepfather. In $A v$ the UK, the Court held in 1998 that the state has a duty under article 3 of the ECHR to protect its inhabitants from physical harm, in particular when such harm reaches the level of severity. ${ }^{23}$ The boy (A) was 9 years old when he was being hit with a garden cane repeatedly by his stepfather. The stepfather was charged with assault occasioning actual bodily harm. In court he, argued that hitting A had been necessary and reasonable; the jury found the stepfather not guilty by reason of the stepfather's hitting being considered "reasonable chastisement". ${ }^{24}$ The European Court (ECtHR) held that the assessment of the "minimum level of severity" that must be attained should not be limited to the act (of alleged cruel, inhuman, and degrading treatment) as such but should take into account all the circumstances of the case, such as the nature and context of the treatment, its duration, its physical and mental effects, and, in some instances, the sex, age, and state of health of the victim. ${ }^{25}$ According to the ECtHR, the law did not provide adequate protection against treatment or punishment contrary to article 3 because according to English common law, the "reasonable chastisement" defense can be used to legitimize physical harm to a child. The Court requires States to take measures to ensure that individuals within their jurisdiction are not subjected to inhuman or degrading treatment or punishment, including such ill-treatment administered by private individuals. ${ }^{26}$

The ECtHR has not made clear whether mild corporal punishment would be permissible, meaning whether it would meet the "minimum level of severity" threshold. It does seem likely that the threshold for establishing a violation of article 3 ECHR is lower today, especially in light of a number of decisions that have highlighted the importance of the age of the victim to the assessment of whether the threshold has been reached. According to O'Mahony, it seems unlikely that the threshold would be abandoned altogether for the mere reason that the victim was a child (O'Mahony, 2019a). But some less severe instances of corporal punishment could fall under Article 8 ECHR instead. There is a separate obligation deriving from article 8 to enact effective laws to protect children from abusive conduct $^{27}$ (O'Mahony, 2019b). It does seem likely that the threshold for establishing a violation under article 8 would be lower than in an article 3 case. O'Mahony states that in recent years, a complaint of a violation of article 8 ECHR by virtue of the absence of an outright prohibition of corporal punishment would have a strong chance of success (O’Mahony, 2019a).

In 2001, the Court ruled in Z. and Others $v$ United Kingdom in a situation of longterm abuse and severe neglect of four young siblings - not resulting in criminal law

\footnotetext{
${ }^{23}$ This means that where parents use the application of physical force (provided it falls under "reasonable" chastisement) to discipline their child, it will amount to a deference in a charge of assault; parents will be acquitted and will not have a criminal record. In England and Wales, parents can justify common assault or battery of their children as "reasonable punishment" and can use this defense.

${ }^{24}$ See also ECtHR 25 March 1993, Costello-Roberts v UK, 13134/87.

${ }^{25}$ ECtHR 23 September 1998, A. v UK, 100/1997/884/1096, para. 22-24.

${ }^{26}$ ECtHR 12 November 2013, Söderman v Sweden, appl.no. 5786/08.

${ }^{27}$ ECtHR 10 May 2001, Z and Others $v$ UK, 29392/95, para. 73.
} 
investigations - that the State has an obligation to protect children against abuse and neglect in the family sphere. ${ }^{28}$ The principle relating to cases in which the state is liable under article 3 was expanded by the Court in this ruling to situations in which the parent or carer is responsible for secretly abusing the child without the State authorities having any direct influence. In Z. and Others $v$ United Kingdom, the four siblings suffered long-time abuse, while the local authority had been aware of the circumstances but did not adequately respond or remove the children from home. The ECtHR held that the State has a positive obligation to protect children from abuse and neglect when it knows or should have known that the child is at risk at home. Repeated warnings or reports or other weighty evidence of abuse can be decisive.

The ECtHR further expanded this caselaw in 2002 to cover cases of sexual abuse in $E$ and others $v$ United Kingdom. This case concerned four siblings who claimed that the local authority had failed to protect them from sexual abuse by their mother's partner. The local authority should have been aware of past sexual abuse in the home by the mother's partner, who had previously been convicted and sentenced to 2-year probation involving indecent behavior against two young sisters in the family. The stepfather had been placed on probation on the condition that he would not reside in the home of the four siblings, but he continued to reside in the family home. The Court held that the lack of communication and cooperation contributed to the violation of article 3 . The failure to take reasonably available measures which could have had a real possibility to alter the outcome or mitigate the harm was sufficient for the Court to hold the State responsible. The Court further held that the pattern of lack of investigation, communication, and cooperation of the relevant authorities must be regarded as having had a significant influence on the course of events, and effective management of their responsibilities might have been expected to avoid or, at least, minimize the risk or the damage suffered (Bruning \& Zlotnik, 2019). To sum up, the importance of cooperation and information-sharing between child protection professionals was emphasized; the failure of a child protection system to cooperate and act upon the information it possessed can result in a violation of the State's positive obligations under article 3.

The ECtHR ruled in the same vein in a recent case against France. ${ }^{29}$ The case concerned the death of an 8-year-old girl as a result of abuse by her parents. Two French child protection associations filed complaints against France about a violation of article 3 based on the premise that the State had not sufficiently protected the girl against the tragic abuse at home. The Court concluded that the reports of teachers about suspicions of abuse had triggered the State's positive obligation to carry out investigations, but the measures had not been sufficient. When responding to the reports, several flaws in swiftly and effectively investigating the home situation instead of simply setting the matter aside had resulted in a violation of article 3.

In conclusion, the State has a substantive positive obligation to protect children against abuse and neglect in the family since the State has the duty to realize the right to protection against inhuman or degrading treatment or punishment. To fulfill this obligation, States have to take legislative action (e.g., removal from law and practice

\footnotetext{
${ }^{28}$ ECtHR 4 June 2020, Association Innocence en Danger and Association Enfance et Partage v. France, appl.nos. 15343/15, 16806/15.

${ }^{29}$ ECtHR 28 January 2014, O'Keeffe v. Ireland (GC), 35810/09.
} 
of the "reasonable chastisement" defense). Furthermore, action is needed with regard to effective child protection systems to interfere in family life to protect children against all forms of violence when the responsible child protection authorities knew or ought to have known that children are at risk at home. Even when violence in the home setting is disguised and hidden, the State should take action whenever signs of unsafety can or should be discerned. Monitoring families, for example, via child protection orders and social workers, is not sufficient to fulfill the positive obligations under article 3 CRC when multi-disciplinary working methods and information-sharing between various professionals who support the family are lacking.

Whereas States nowadays have incorporated legislation to protect children from (severe forms of) violence in their circle of trust, the main challenges to be addressed concern hands-on implementation of multi-agency cooperation, information-sharing, and taking the lead by responsible authorities when suspicions of child abuse or neglect arise and actions need to be taken. The ECtHR does not present key elements of an effective child protection system when interpreting individual article 3 ECHR complaints. Nevertheless, the ECtHR underscores that effective protection of children against violence does not only comprise legislative action, but requires that individual child protection workers take their responsibility and effectively respond to suspicions of abuse or neglect.

\section{Violence in the Public Domain}

Children do not only risk abuse or neglect in the family, but can also become a victim of violence in the public domain, for example, in schools. Children who are living in alternative care after a removal from the family home even have a higher risk to be victim of abuse or neglect (Committee De Winter, 2019). In the last decade, several national inquiry committees into sexual abuse of children in alternative care, such as foster care and residential care, have concluded in historical child abuse reports that many children in care were victim of abuse or neglect and that the State was responsible (e.g., Royal Commission into Institutional Reponses to Child Sexual Abuse, 2017; the Commission to Inquire into Child Abuse Committee, 2009; Wright, 2017).

In the landmark case of O'Keeffe v. Ireland, the Grand Chamber of the ECtHR decided in 2014 that Ireland had not fulfilled its positive obligations under article 3 of the ECHR, since it did not provide an effective protection mechanism for acts of abuse against minors in schools (European Union Agency for Fundamental Rights and CoE, 2015; O’Mahony \& Kilkelly, 2014). ${ }^{30}$ In this case, several young girls faced sexual abuse in an Irish National School in the 1970s. At the time, national schools were recognized and paid for by the Irish State, whereas the management and administration were entrusted to the Church. The applicant, a young pupil of 9 years old at the time, was repeatedly subjected to sexual abuse by one of the school teachers. The Grand Chamber of the ECtHR ruled that, based on various reports, the State should have been aware of the potential risks of sexual abuse in schools. At the time, there was no adequate procedure in place which would have allowed a child or a parent to complain directly to the state about acts of abuse. Moreover, there were no supervision mechanisms of teachers' behavior and treatment of children. According to the Court, an

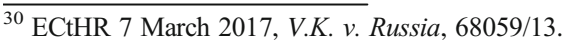


effective protection mechanism for acts of abuse or neglect against children in schools should have been provided by the State; the Irish system in the 1970s did not contain sufficient mechanisms of child protection. Important to note is that the Court emphasized that "a State cannot absolve itself from its obligations to minors in primary schools by delegating those duties to private bodies or individuals." In other words, delegation is no justification for the State. The State has a duty to protect children against the foreseeable risk of violence against unidentified individuals (O'Mahony, 2019b).

In 2017, the ECtHR repeated that the State has a responsibility with regard to a nursery school that provides basic public service where a young boy of 4 years old was subjected to violence committed by the teachers. ${ }^{31}$ According to the Court, the State bore direct responsibility for the wrongful acts: the ill-treatment by teachers of the nursery school was committed on school grounds during school hours, and therefore, there was a very strong link with the state, also with regard to funding, real estate, and equipment. Furthermore, nursery schools provide basic public service, and therefore, teachers may be regarded as state agents. In this case, the State was held responsible for a violation of the substantive aspects of article 3. It can be concluded that when States delegate duties regarding children to others, monitoring and an effective reporting system are vital elements of guaranteeing the child's right to protection against (sexual) abuse and therefore key to an effective child protection system.

In 2021, the Grand Chamber of the ECtHR ruled in the same vein about the importance of monitoring and an effective reporting system when deciding about allegations of sexual abuse in an orphanage of three young siblings of 12, 10, and 9 years old who were adopted by an Italian couple. ${ }^{32}$ The adoptive parents lodged a complaint with the Italian police concerning the sexual abuse of the children during their placement in an orphanage in Bulgaria and informed the Italian media alleging large-scale sexual abuse of children in the orphanage. The Bulgarian authorities were informed about the complaint, and three preliminary investigations were opened in Bulgaria. The investigations were discontinued for lack of evidence. A Chamber of the Court held in a judgment of 17 January 2019 that there had been no violation of articles 3 and 8 ECHR. However, the Grand Chamber ruled in a divided decision (9-8) that the Bulgarian authorities had not taken all reasonable measures to shed lights on the facts and had not undertaken a full and careful analysis of the evidence before them. Although Bulgaria had fulfilled the substantive positive obligations to put in place an appropriate legislative and regulatory framework and to take appropriate operational measures, the procedural obligations were not fulfilled. The investigating authorities had not made use of the available investigation and international cooperation mechanisms and had not attempted to interview the children named by the applicants who had left the orphanage in the meantime. Overall, the omissions observed led to the conclusion that the investigation had not been effective for the purposes of article 3 ECHR. The Grand Chamber concluded that there had been a violation of the procedural limb of article 3 ECHR.

\footnotetext{
${ }^{31}$ ECtHR 17 January 2019, X. and Others v. Bulgaria, 22457/16.

32 ECtHR 4 December 2003, M.C. v. Bulgaria, 39272/98. See also ECtHR 24 January 2012, P.M. v. Bulgaria, 49669/07, in which authorities took more than 15 years to complete investigation of the rape of a 13-year-old girl.
} 
In conclusion, States are responsible for child protection in schools and institutions and cannot absolve itself from its obligation to protect children against all forms of violence while in school or in care. When States take actions to put in place an appropriate legislative and regulatory framework, ensure the safety of children, organize an effective reporting system, and structurally monitor children's safety, they respond to substantive positive obligations that follow from article 3 ECHR. Furthermore, States have procedural duties to carry out an effective investigation in order to fulfill the positive obligations. Thus, both a monitoring system and an effective reporting system can be seen as crucial elements of effective child protection systems that respond to violence against children.

\section{Effective Investigations into Allegations of Violence Against Children}

The ECtHR's caselaw has thus made clear that States have a positive obligation to provide practical and effective protection in situations of child abuse and neglect. Not only does this include an adequate legal framework and actions to take the necessary legislative or other measures to ensure that all forms of child abuse and neglect are criminalized, alongside organizing an effective monitoring and reporting system and ensuring that professionals cooperate and share information about suspicions of abuse or neglect, but the positive obligations also encompass effective law enforcement. States must conduct effective investigations into allegations of abuse or neglect. In M. C. v Bulgaria, the ECtHR noted that an allegation of rape of a 14-year-old girl by two individuals after she had gone out one evening should lead to an effective investigation. ${ }^{33}$ The Bulgarian authorities had failed to conduct such an investigation because the victim could not show physical opposition to the act of rape and such cases were generally dismissed. The European Court found that such a standard of proof, and thus the authorities' investigation, was in breach of article 3 of the ECHR: such a standard of proof was not in accordance with factual realities concerning victims of rape. According to the Court, States have a positive obligation both to enact criminal legislation to effectively punish sexual abuse and to apply this legislation through effective investigation and prosecution.

Another example of an ineffective law enforcement system can be found in D.M.D. $v$ Romania. $^{34}$ In this case, a young boy was allegedly abused by his father. The proceedings lasted over 8 years and resulted in the father's conviction of physically and mentally abusing his child with a suspended prison sentence. The Court took a principled stance, which is very rare: Member States should strive to expressly and comprehensively protect children's dignity. In practice, this requires an adequate legal framework affording protection to children against domestic violence, including effective deterrence against such serious breaches of personal integrity, reasonable steps to prevent ill-treatment of which the authorities have, or ought to have, knowledge, and effective official investigations where an individual raises an arguable claim of illtreatment. According to the Court, assuring basic dignity to the child means that there

\footnotetext{
${ }_{33}$ ECtHR 3 October 2017, D.M.D. v. Romania, appl.no. 23022/13. See also ECtHR 20 March 2012, C.A.S. and C.S. v. Romania, appl.no. 26692/05 (authorities took 5 years to investigate the rape when the applicant was 7 years old).

${ }^{34}$ ECtHR 23 March 2010, M.A.K. and R.K. v the United Kingdom, appl.nos. 45901/05 and 40146/06.
} 
can be no compromise in condemning violence against children, whether accepted as "tradition" or disguised as "discipline". Children have more, not less, protection from violence, including from domestic corporal punishment, the latter being invariably degrading (par. 50). The European Court referred both to the $\mathrm{CRC}$ and the developing psychological perspective in jurisprudence with regard to respect for the dignity of the child. "Children's uniqueness - their potential and vulnerability, their dependence on adults - makes it imperative that they have more, not less, protection from violence, including from domestic corporal punishment, the latter being invariably degrading" (D.M.D. v Romania, para. 50). Several shortcomings in the proceedings were defined: the child-victim was not offered any form of compensation for the excessive length of the case nor received any compensation for the abuse to which he had been subjected, and the domestic courts' approach to the issue of child abuse in the family undermined respect for the child's dignity. The Court concluded that the investigation into the allegations of ill-treatment was ineffective, and thus, there had been a violation of article 3 of the ECHR.

To conclude, it is clear from ECtHR's caselaw that Member States have a positive obligation to protect children's dignity which requires an adequate legal framework to protect children against abuse and neglect falling under the scope of article 3 of the ECHR, including effective official investigations where an arguable claim of illtreatment has been made (procedural obligation). Furthermore, reasonable steps to prevent ill-treatment of which the authorities had, or ought to have had, knowledge, should be taken (substantive obligation).

What it comes down to is not only an adequate legal framework and sufficient policy papers, but professional conduct amounting to putting adequate measures genuinely into practice.

\section{Family Life and Child's Removal from Home}

When analyzing key elements of child protection systems that can be distinguished from ECtHR caselaw, the right to respect for family life as laid down in article 8 ECHR is - besides the right to protection against violence according to article $3 \mathrm{ECHR}$ - the second core relevant human rights pillar to be distinguished. The right of the child not to be separated from her or his parents unless this is necessary in her or his best interests is enshrined in article 9 para. 1 CRC. Children and parents belong together and have the right to respect for family life without state intervention. Still, violence at home or other serious threats to the child's development can lead to the child's removal and separation from parents. Placement of a child in alternative care is generally considered to be undesirable, if it is possible to create acceptable conditions for the child while living with his or her parents (Guidelines for the Alternative Care of Children, 2010; Sandberg, 2018). Nevertheless, in dangerous situations and when there are reasonable suspicions of child abuse and neglect at home, state authorities will have to remove children in their best interests. Parents and children can then claim that their article 8 ECHR rights have been violated when there are issues of uncertainty or vagueness in the laws regarding child removal or the nature of the removal seems disproportionate. In M.A.K. and R.K. v United Kingdom ${ }^{35}$ the ECtHR held that:

$\overline{{ }^{35} \text { ECtHR } 18 \text { June 2013, } R M S \text { v }}$. Spain appl.no. 28775/23, para. 72. 
mistaken judgments or assessments by professionals do not per se render childcare measures incompatible with the requirements of Article 8 . The authorities, both medical and social, have duties to protect children and cannot be held liable every time genuine and reasonably held concerns about the safety of children vis-à-vis members of their family are proved, retrospectively, to have been misguided. (para. 69)

The Court applies different standards when referring to the initial decision to remove a child from parental care and the decision to keep the child in care or limit parental visitation and contact. Whereas with regard to the initial decision to remove the child from home, the responsible authorities enjoy a wide margin of appreciation, the subsequent decisions to keep the parents and child apart enjoy a smaller margin of appreciation, and the State has the positive obligation to reunite children with parents (Bruning \& Florescu, 2016). The basic assumption is that separation will only be temporary, for the least amount of time possible, ${ }^{36}$ and efforts should be made to ensure that children are reunited with their parents. Nevertheless, the ECtHR emphasizes that in some circumstances, the interests of the child not to have his or her de facto family situation changed again after a considerable period of time has passed may override the interests of the parents to have their family reunited. ${ }^{37}$ Still, a strict scrutiny is called for such kind of limitations on parental rights and access. When it comes to newborn babies, extraordinary compelling reasons must exist to justify a separation from the mother at birth. ${ }^{38}$ Hence, child protection systems should be very reluctant in separating families. Decision-making processes should aim to keep families together and offer social services support to keep families intact.

Another important element that can be distilled from European caselaw that is closely connected to decision-making processes is the right of the parent and the child to be involved in these processes. This element will be discussed in the next section.

\section{The Right of the Child to Be Heard and Other Procedural Principles}

Article 12 CRC established the right of the child, capable of forming her or his own views, to express these views freely in all matters affecting her or him and the rule that these views have to be given due weight in accordance with the age and maturity of the child. Para 2 of this provision rules that the child shall be given the opportunity to be heard in any judicial and administrative proceedings affecting the child. In such proceedings, the child can be heard directly or through a representative or an appropriate body (article 12, para. 2). The CRC Committee issued in 2009 a General Comment with inter alia a literal analysis of article 12, special attention to the child's right to be heard in civil, penal, and administrative proceedings, the link with other articles of the $\mathrm{CRC}$; and the implementation of the right of the child to freely express her or his views in the family, in health care, in education, in the workplace, and in

\footnotetext{
$\overline{36}$ ECtHR 14 January 2003, K.A. v. Finland, appl.no. 27751/95; see also ECtHR 27 June 1996, Johansen v Norway, appl.no. 12750/02.

${ }^{37}$ ECtHR 12 July 2001, K. and T. v Finland, appl.no. 25702/94.

${ }^{38}$ The EU mapping of child protection systems shows that 11 Member States of the EU have set a minimum age above which authorities must hear the child. Below that age the realization of the right to be heard depends on the respective authorities. That is also true for the countries without a minimum age; EU Mapping p. 22.
} 
alternative care (General Comment CRC No. 12). In the context of this article, we have to limit ourselves to some information from this General Comment relevant for the implementation of this right in the context of child protection systems.

The Committee emphasizes that there is no age limit in article 12 and discourages State parties to introduce age limits that may restrict the child's right to be heard (General Comment CRC No. 12, para. 21). ${ }^{39}$ In child protection proceedings, children should as much as possible be heard directly by the judge (of a family or juvenile court). If the child is heard via a representative, the parent(s), a lawyer, or a social worker, this person should have sufficient knowledge and understanding of the various aspects of the decision-making process and has the obligation to transmit the views of the child correctly to the decision-maker (General Comment CRC No. 12, para. 36; Mol, 2019). The law should ensure that children in alternative care shall have an opportunity to express their views and that these views are given due weight in matters of their placement the regulations of care in foster families or in institutions and their daily life (General Comment CRC No. 12, para. 97). The child has the right to be informed about the outcome of the (decision-making) process with an explanation of how her or his views were taken into account. This feedback may prompt the child to insist, agree, or make another proposal or, in the case of a judicial or administrative procedure, file an appeal or a complaint (General Comment CRC No. 12, para. 45).

In cases of separation of the child from her or his parent(s), article 9 CRC contains a specific procedural rule: in proceedings on the possible separation of the child from her/ his parent(s), all interested parties, at least the parent(s) and the child, shall be given an opportunity to participate in the proceedings and make their views known (Art. 9, para. 2).

The ECHR does not contain any provision acknowledging the right of the child to be heard in judicial or administrative proceedings. The ECtHR had understandably some difficulties in finding a legal basis for the right of the child to be heard in legal proceedings. Initially the views of the child were considered to be important, e.g., in matters of contact between the parent and her or his child after divorce. If the child did not want to have any more contact with the father, the decision of a local court not to enforce the contact order was not considered as a violation of the father's right to respect for his family life (Article 8 para. 1 ECHR). ${ }^{40}$ In the case Sahin v Germany the ECtHR observed that "it would be going too far to say that domestic courts are always required to hear a child in court on the issue of access to a parent not having custody, but this issue depends on the specific circumstances of each case, having due regard to the age and maturity of the child" (in this case the child was between 2 and 5 years old during the proceedings). ${ }^{41}$ So there was a margin of appreciation in the decision to hear a child which, for instance, includes the decision not to order an opinion of a psychologist and to take the views of the 13 -year-old child at face value. ${ }^{42}$

However, in 2015, the ECtHR clearly recognized the right of the child to be heard in legal proceedings as part of the right to respect for private and family life enshrined in

\footnotetext{
${ }^{39}$ ECtHR 23 September 1994, Hokkanen v. Finland, Series A no 299-A, 19 EHRR 139, para. 61.

${ }^{40}$ ECtHR 8 July 2003, Sahin v. Germany, no. 30943/96, para. 67.

${ }^{41}$ ECtHR 8 July 2003, Sommerfield v. Germany, no. 31871/96, para. 71. See for a similar decision ECtHR 18 December 2018, Khusnutdinov \& X v. Russian Federation, ECLI:CE:ECHR:2018:1218JUD007659812.

42 ECtHR 3 September 2015, $M$ \& $M$ v. Croatia, para. 171-172 and 181. ECLI:CE:ECHR:2015:0903JUD001016113.
} 
article $8 \mathrm{ECHR}$. Not hearing the child is a violation of this provision. With reference to article $12 \mathrm{CRC}$ and General Comment No. 12 (mentioned above), it took the view that "it cannot be said that children capable of forming their own views were sufficiently involved in the decision-making process if they were not provided with the opportunity to be heard and thus express their views". 43 This was confirmed in 2016 in the case N.TS. a.o. $v$ Georgia involving children of 10 and 6 years old. In that case, the European Court also dealt with the matter of representation of the children by the Social Service Agency. The Court was of the view that this representation could not be considered as sufficient and meaningful. The agency had not maintained a structural and frequent contact with the children. ${ }^{44}$

In conclusion, the flawed representation of the children and thus the failure to duly represent and hear the views of the children undermined the procedural fairness of the decision-making process, and therefore, article 8 ECHR was violated. The caselaw of the ECtHR shows that the views of the child should not only be heard but also be taken into account in accordance with the age and maturity of the child (article 12, para. 1 CRC). Participation of children in the decision-making process therefore constitutes an important element of an effective child protection system.

\section{Procedural Rights of Parents}

The ECtHR has also emphasized the right of a parent to be involved in any decisionmaking procedure that affects her or his right to respect for her or his privacy and family life. Article 8, para. 1 ECHR requires that such procedure must be sufficient to protect her or his interests. ${ }^{45}$ This right includes inter alia the right to access for parents to reports about their children that could lead to the adoption of their children ${ }^{46}$ and that material on which a placement of a child in alternative care is based should be made available to her or his parents even if they did not ask for it. ${ }^{47}$ In emergency cases, parents may be excluded from information authorities rely on for their decision to remove the child from the parent(s), ${ }^{48}$ but the imminent danger for the child and the necessity to exclude parent(s) from information have to be proven. ${ }^{49}$ An example was the abrupt removal of a child from her mother because she was suspected of suffering from the Munchausen by proxy syndrome. It was not sufficiently explained why the doctors could not discuss their concerns with the mother, and she could therefore not contest the reliability of the information the doctors relied on. ${ }^{50}$ Furthermore, parents have the right to an oral hearing ${ }^{51}$ and the right to legal representation in the complex

\footnotetext{
${ }^{43}$ ECtHR 2 February 2016, N.TS. e.a. v. Georgia, para. 75. ECLI:CE:ECHR:2016:0202JUD007177612.

${ }^{44}$ ECtHR 8 July 1987, Wv. UK, A 121 (1987); 10EHRR 29 para. 64 and 77-79.

${ }^{45}$ ECtHR 24 February 1995, McMichael v. UK, A 307-B (1995); 20EHRR 205 para. 101-105.

${ }^{46}$ ECtHR 10 May 2001, TP and KM v. UK, 2001-V; 34 EHRR 42 para. 72.

${ }^{47}$ ECtHR 8 July 1987, $W v U K$, A 121(1987) 10 EHRR 29, para. 105-111; ECtHR 12 July 2001, $K \& T v$ Finland, 2001-VII; 31 EHRR 484, para. 168.

${ }^{48}$ ECtHR 14 January 2003, K A v. Finland, para. 102-104.

${ }^{49}$ ECtHR 17 December 2002, Venema v. The Netherlands, para. 96-97.

${ }^{50}$ ECtHR 27 April 2000, L v. Finland, para. 132.

${ }^{51}$ ECtHR 16 July 2002, $P, C$ and $S$ v. UK, 2002-VI; 35 EHRR 1075 para. 99-100.
} 
and sensitive cases of child protection because the Court accepts a very wide margin of appreciation to the domestic authorities. ${ }^{52}$ Significant delays in legal proceedings, partly attributed to the authorities, constitute a violation of article $8 \mathrm{ECHR}^{53}$

\section{Some Conclusions}

Following from relevant caselaw of the ECtHR, regarding articles 3 and 8 of the ECHR focusing on individual complaints and specific circumstances of the case, several key components of effective child protection systems can be distilled. States have a positive obligation to take legislative action to protect children from violence both in the family and in the public domain such as in schools and in institutions. Furthermore, legislation prohibiting and tackling violence against children is not sufficient. Effective implementation actions - such as effective official investigations where an arguable claim of ill-treatment has been made, multi-agency cooperation and information-sharing, effectively responding to child abuse reports and a monitoring system in case state responsibilities are delegated - form part of another positive obligation of States to guarantee the child's right to protection against all forms of violence according to the ECtHR. With this in mind, when taking actions, one should be reluctant to remove children from the home and be aimed at guaranteeing sufficient contact and reuniting parents and child; this follows from article 8 ECHR. Besides, children and parents should be given the opportunity to effectively participate in the decision-making process, and their views should be taken seriously.

Moreover, several of the discussed ECtHR decisions reveal important flaws in effective child protection systems that can be found in professional conduct of responsible authorities. Often States have taken legislative measures to protect children against violence and have developed effective policies on paper, but in daily practice when implementing laws and policies, shortcomings arise, such as hands-on multiagency cooperation and information-sharing and taking the lead and responsibilities instead of limiting actions with the risk of children becoming or remaining victims of abuse without sufficient State protection. When actions are indeed taken and children are separated from their parents, child protection services often fail to sufficiently invest in supporting the parents in order to reunite them with their child - a long-term future perspective of the child without parents is often the main approach - and parents and children often cannot fully participate in the proceedings. Delicately balancing these various positive obligations remains hard and needs permanent attention.

\section{Main Findings and Recommendations}

At the European level, both the European Union and the $\mathrm{CoE}$ advocate and promote the development and implementation of an integrated national child protection system. There is a large degree of consensus regarding the key elements of the structure of

\footnotetext{
$\overline{52}$ ECtHR 8 July 1987, $W v$. UK, A 121 (1987); 10 EHRR 29, para. 62-65.

${ }^{53}$ See in this regard inter alia General Comment No 4 (2003) of the CRC Committee on Adolescent health and development in the context of the Convention on the Rights of the Child. UN Doc. CRC/GC/2003/4, 1 July 2003 and General Comment No.20 (2016) on the implementation of the rights of the child during adolescence. UN Doc. CRC/C/GC/20, 6 December 2016.
} 
national integrated child protection systems. These key elements are more or less the same as the ones recognized by the CRC Committee in its recommendation to establish a National Coordinating Framework on violence against children (General Comment CRC No. 13 paras. 68-71) and in UNICEF's child rights approach to child protection. The obvious question is: Do all these ideas and words have an impact in practice?

In 2015, the EU provided a beginning of an answer in indicating that the practical impact is mixed. National policies on child protection do not always come with concrete action plans with time bound and measurable goals; in all, 28 Member States all candidates for becoming a foster parent are regularly vetted; 15 Member States have the legal obligation to report cases of child abuse, neglect, and violence for all professionals working with or for children; the right of the child to be heard is enshrined in the laws of all Member States; and 11 States set an age of the child above which they must be provided with an opportunity to express their views.

Cross-sectoral coordination and cooperation are considered to be critical elements of an effective child protection system. However, implementation of these elements turns out to be problematic inter alia due to lack of (adequate) authority of the body charged with coordination and to lack of clarity of the responsibilities. However, intersectoral cooperation and coordination are not only a matter of organization but first and foremost a responsibility of the professionals working in the field of child protection. The ECtHR emphasized in the cases $E$ and others $v$ UK (2002) and Association Innocence en Danger and Association Enfance et Partage v. France (2020) the importance of cooperation and information-sharing between child protection professionals. Regarding information-sharing, child protection professionals struggle with the need to protect the privacy of children and their families (Art. $16 \mathrm{CRC}$ ). This matter did not get much attention in the documents and caselaw we dealt with in our research. We therefore recommend that inter alia the CRC Committee, the EU/FRA, and the CoE provide specific guidance for professionals in the child protection field in their efforts to find in concrete cases a balance between the right of the child to effective protection and her/his right and that of her/his family to privacy.

Since the beginning of this century, there has been significant and increasing attention for violence against children at the international and national levels. This may explain why the proposals (CRC Committee, UNICEF, EU, and CoE) for an integrated child protection system are very much, and sometimes exclusively, linked to the prevention of and effective intervention in cases of violence against children. It should be noted that investigation of cases of child abuse is required in article 19, para. $2 \mathrm{CRC}$ and elaborated in General Comment No. 13 para. 51, while the ECtHR in the case D.M.D. v Romania emphasized the importance of effective official investigations where an arguable claim of ill-treatment has been made. This is an example of a development in which obligations under the $\mathrm{CRC}$ are playing an increasing role in the jurisprudence of a regional Court on Human Rights.

Children are obviously suffering from other adverse events in connection with violence. The challenge for the further development of an integrated child protection system is the explicit and clear inclusion of vulnerable children (too often not getting adequate attention), such as children with disabilities, belonging to ethnic minorities or indigenous people, and unaccompanied and separated asylum-seeking children. In 
addition, an integrated child protection system should pay more attention to mental health problems of children both in terms of prevention and intervention. ${ }^{54}$ The mapping of the performance of the Member States of the EU and the CoE should take place at least every 5 years. The results should be published and be provided with country-specific follow-up with a view to further strengthen their efforts to guarantee every child within their jurisdiction with the best prevention and protection possible.

The development and implementation of an integrated and effective child protection system are also a matter of human rights of children and their parents, as acknowledged by the CRC Committee, UNICEF, the European Union, and the CoE. The caselaw of the ECtHR shows that articles 3 and 8 ECHR are not only a source of negative but also of positive obligations of all 47 European states party to this Convention. The positive obligations entail that a State can be held responsible for the failure of, e.g., child protective services or social services, to take the necessary measures for the protection of a child who, as they know or should know, is a victim of child abuse or at are at risk of becoming a victim. Delegation or decentralization of certain responsibilities does not diminish the obligation of the State for the implementation of the rights recognized in the ECHR and the CRC. Furthermore, a State party to the ECHR has the obligation to provide an effective protection mechanism for acts of abuse in schools. The failure to do so makes the State responsible for acts of abuse that happen in schools. The ECtHR underscores the importance of the parent's right to respect for family life. The removal of a child from the parental home without consultation with the parents should be limited to very extreme cases of danger for the child (Art. 9, para. 1 CRC). It is remarkable that article 8 ECHR became an important source of procedural rights of both the parents and the child. Re the latter the ECtHR increased its reference to article $12 \mathrm{CRC}$ and the related General Comment No. 12. One of the core messages of the caselaw of the ECtHR to all actors in the child protection system is that no measure of child protection should be used without first informing and consulting with the child (or her/his representative) and the parents. In this context, the ECtHR underscores the right of the child to respect for her/his dignity which should be a key feature of all actions of agencies and professionals in the field of child protection.

There has been some mentioning of children's rights in the documents of the EU and the $\mathrm{CoE}$, but we recommend that these bodies develop a guide in which the rights of the child and the parents as recognized in the CRC and the ECHR and the caselaw of the ECtHR are presented with adequate elaborations of their relevance for the practice of all actors in the child protection system. A child-friendly and parent-friendly guide should be made available, e.g., via the Internet. An integrated child protection system can only be effective if it fully respects the rights of the child and of parents.

Finally, we recommend that in legislation, policies, and practice, systematic attention be given to their contributions to achieving the child-specific targets on the elimination of all forms of violence against children, including sexual abuse and exploitation, trafficking, and child labor in the UN Sustainable Development Goals. These targets should be achieved by 2030, and that requires inter alia the setting of priorities depending on the national circumstances and the provision of adequate financial and human resources not only for protection but also for prevention. All Member States of the UN have committed themselves to all possible actions to achieve

$\overline{{ }^{54} \text { ECtHR } 23 \text { September 1998, A. }}$ v. UK, appl.no. 100/1997/884/1096. 
the SDGs, including the child-specific targets. Agencies like the CRC Committee, UNICEF, the EU, and the CoE and national and international NGOs should support States as much as possible in these actions.

Open Access This article is licensed under a Creative Commons Attribution 4.0 International License, which permits use, sharing, adaptation, distribution and reproduction in any medium or format, as long as you give appropriate credit to the original author(s) and the source, provide a link to the Creative Commons licence, and indicate if changes were made. The images or other third party material in this article are included in the article's Creative Commons licence, unless indicated otherwise in a credit line to the material. If material is not included in the article's Creative Commons licence and your intended use is not permitted by statutory regulation or exceeds the permitted use, you will need to obtain permission directly from the copyright holder. To view a copy of this licence, visit http://creativecommons.org/licenses/by/4.0/.

\section{References}

Bruning, M. R., \& Florescu, S. (2016). Discharge of parental authority. In C. G. Breedveld-de Voogd, A. G. Castermans, M. W. Knigge, T. van der Linden, \& H. A. ten Hoeve (Eds.), Core concepts in the Dutch civil code (pp. 169-186). Kluwer.

Bruning, M. R., \& Zlotnik, D. (2019). Cooperation and the right of child abuse victims to protection and health: Lessons from the Netherlands. In J. Dorscheidt \& J. E. Doek (Eds.), Children's rights in health care (pp. 301-333). Brill Publishers.

$\mathrm{CoE}$ (2009). Policy guidelines on integrated national strategies for the protection of children from violence. Retrieved from https://rm.coe.int/168046d3a0.

$\mathrm{CoE}$ (2010). Guidelines of the Committee of Ministers of the CoE on child-friendly justice. Retrieved from https://rm.coe.int/16804b2cf3.

CoE. (2019). A life free from violence for all children-Report on action taken by the CoE and member states. $\mathrm{CoE}$.

$\mathrm{CoE}$ and European Court of Human Rights (2011). Child sexual abuse and child pornography in the Court's case-law. Research report. CoE and European Court on Human Rights. Retrieved from https://echr.coe. int/Documents/Research_report_child_abuse_ENG.pdf.

Committee on the Rights of the Child (2009). General Comment No. 12: The right of the child to be heard (CRC/C/GC/12). Retrieved from https://www.refworld.org/docid/4ae562c52.html.

Committee on the Rights of the Child (2011). General Comment No. 13: The right of the child to freedom from all forms of violence (CRC/C/GC/13). Retrieved from https://www.refworld.org/docid/4e6da4922. html.

Committee on the Rights of the Child (2013). General comment No. 14: On the right of the child to have his or her best interests taken as a primary consideration (art. 3, para. 1), 29 May 2013, CRC /C/GC/14.

Committee to Inquire into Child Abuse and Neglect (Committee De Winter). (2019). Inadequate protectionViolence in Dutch youth care from 1945 - Present; Dutch report: "Onvoldoende beschermd". Committee to Inquire into Child Abuse and Neglect.

Doek, J., Krappmann, L., \& Lee, Y. (2020). The role of the Committee on the Rights of the Child in monitoring child abuse and neglect. Child Abuse \& Neglect, 110(Part 1 December 2020), 104517.

Donnelly, A. C. (2002). An international movement to end child abuse. ISPCAN.

Dutch Safety Board. (2011). About the physical safety of the young child - Thematic study: Cases of child abuse with a fatal or near fatal end. Dutch Safety Board.

European Commission. (2012). The EU strategy towards the eradication of trafficking of human beings 20122016. Resource document. European Commission. Retrieved from https:/ec.europa.eu/anti-trafficking/ sites/antitrafficking/files/eu_strategy_towards_the_eradication_of_trafficking_in_human_beings_20122016_1.pdf.

European Union Agency for Fundamental Rights. (2015). Mapping child protection systems in the EU. Resource document. European Union Agency for Fundamental Rights. Retrieved from https://fra.europa. eu/en/publication/2016/mapping-child-protection-systems-eu.

European Union Agency for Fundamental Rights and CoE. (2015). Handbook on European law relating to the rights of the child. Publications Office of the European Union. 
Gilbert, N., Parton, N., \& Skivenes, M. (2011). Child protection systems. International trends and orientations. Oxford University Press.

Krugman, R. D., \& Korbin, J. E. (Eds.). (2013). C. Henry Kempe: A 50 year legacy to the field of child abuse and neglect. Springer Science-Business Media.

Langeland, W., Hoogendoorn, A. W., Mager, D., Smit, J. H., \& Draijer, N. (2015). Childhood sexual abuse by representatives of the Roman Catholic Church: A prevalence estimate among the Dutch population. Child Abuse \& Neglect, 46, 67-77.

Merkel-Holguin L., Fluke J. D, \& Krugman R. D. (Eds.) (2019). National systems of child protection. Understanding the international variability and context for developing policy and practice. Springer International Publishing.

Mol, C. (2019). Children's representation in family law proceedings. A comparative evaluation in light of article 12 of the United Nations Convention on the Rights of the Child. International Journal of Children's Rights, 27(1), 66-98.

Munro Review. (2011). The Munro review of child protection: Final report. A child-centered system. Department for Education.

O'Mahony, C. (2019a). Is time running out for corporal punishment under the ECHR? European Human Rights Law Review, 24(1), 55-65.

O'Mahony, C. (2019b). Child protection and the ECHR - Making sense of positive and procedural obligations. International Journal of Children's Rights, 27(4), 660-693.

O'Mahony, C., \& Kilkelly, U. (2014). O'Keeffe v Ireland and the duty of the state to identify and prevent child abuse. Journal of Social Welfare and Family Law, 36(3), 320-329.

Royal Commission into Institutional Responses to Child Sexual Abuse. (2017). Final report. Australia.

Sandberg, K. (2018). Alternative care and children's rights. In U. Kilkelly \& T. Liefaard (Eds.), International human rights of children (pp. 187-213). Springer.

The Committee to Inquire into Child Abuse. (2009). Final report (the 'Ryan-report'). The Committee to Inquire into Child Abuse.

UNICEF. (2019). Strengthening child protection systems: Evaluation of UNICEF strategies and programme performance. UNICEF Evaluation Office.

United Nations (2010). Guidelines for the alternative care of children (UN-doc A/RES/64/142), 24 February 2010.

van Nijnatten, C., Hopman, M., \& Knijn, T. (2014). Child protection victims and the 'evil institutions'. Social Sciences, 3(4), 726-741.

Wright, K. (2017). Remaking collective knowledge: An analysis of the complex and multiple effects of inquiries into historical institutional child abuse. Child Abuse \& Neglect, 74, 10-22.

Publisher's Note Springer Nature remains neutral with regard to jurisdictional claims in published maps and institutional affiliations. 